4. Pro zatverdzhennya Pravyl oformlennya viz dlya v"yizdu v Ukrayinu i tranzytnoho proyizdu cherez yiyi terytoriyu [On approval of the Rules of Visa Requirements for Entry and Transit through Ukraine]. URL: https://www.kmu.gov.ua/ua/. [in Ukr]

5. Andrushko, A. V., Nesterova, I. A. (2016) Zlochynnist' u sferi turystychnoho biznesu: kryminolohichna kharakterystyka ta zapobihannya [Crime in tourism business: criminological description and prevention]: monohrafiya. Uzhhorod : TOV «IVA»,. 220 s. [in Ukr]

6. Lohinov, Ya. Pol's'ki 5-richni vizy: obitsyane stalo real'nym, ale prblemy zalyshylysya [Polish 5-year visas: the promise became real, but the problem remained]. Dzerkalo tyzhnya. 16 zhovtnya $2015 \mathrm{r}$. URL: http://gazeta. dt.ua/international/polski-5-richni-vizi-obicyane-stalo-realnim-aleproblemizalishilisya-_.html. [in Ukr]

7. Nesterova, I. A. Sposoby shakhraystva v sferi turystychnoho biznesu Ukrayiny [Methods of fraud in tourist business of Ukraine]. Chasopys Kyyivs'koho universytetu prava. 2011/1. S. 295-298. [in $\mathrm{Ukr}]$

8. Nesterova I. (2014) O proyavleniyakh moshennichestva v sfere turisticheskoho strakhovaniya [Methods of fraud in the sphere of tourist business of Ukraine]. Legea şi Viaţa. № 4. S. 56-59. [in Russ]

9. Turystychni afery [Tourist scams]: URL: https //sirius.kiev.ua/. [in Ukr]

\title{
Summary
}

The article deals with the study of forensically significant features of the methods of fraud in the sphere of tourist services. Attention is paid to description of methods, clarifying their characteristics, determining the factors that affect their formation on the basis of what they were ordering. Laying the basis of a set of criteria for the classification, all the options of fraudulent activities in the tourism sector are summarized in three groups: fraudulent actions by entities that are authorized to conduct such activities (exercise deception in intent, or about a variety of actions and events) fraudulent actions on the part of the constituent entities, which have no official relationship to the tourism business, but on behalf of such persons. In a separate group of related fraudulent operations by individuals whose activity was expressed in support of actions required to obtain travel services.

Keywords: fraud, travel, contract, of fraud, consumer of travel services, tour operator, travel agent.

UDC 343.21

DOI 10.31733/2078-3566-2019-5-177-183

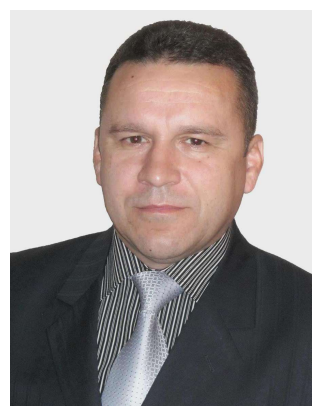

Ihor MITROFANOV

Dr of Law, Ass. Prof.

(Kremenchuk National University

named after Mykhailo Ostrogradskiy)

\section{THE VALUE OF THE MECHANISM OF CRIMINAL LEGAL REGULATION FOR LAW-MAKING}

ІГор МИТрофанов. ЗНАЧЕННЯ МЕХАНІЗМУ КРИМІНАЛЬНО-ПРАВОВОГО РЕГУЛЮВАННЯ ДЛЯ ЗАКОНОТВОРЕННЯ. Проаналізовано механізм кримінально-правового регулювання з точки зору його структури. Розглядаються ключові категорії цього механізму норми кримінального права та кримінально-правові відносини. Механістичний підхід до розуміння механізму кримінально-правового регулювання дозволяє побачити його структуру та фактично уможливлює усвідомлення його динаміки. Такий підхід дозволяє досягти мети роботи моделювання концепту механізму кримінально-правового регулювання, я кому норма кримінального права визнається не лише базовим елементом, а конструкцією, в якій містяться практично весь інструментарій для функціонування такого механізму з метою виконання завдань КК України, а також виявляється значення розглядуваного механізму. Виводиться значення механізму кримінально-правового регулювання для законотворення через конкретні приклади законодавчих новел.

Зроблено висновок, що механізм правового регулювання останнім часом розуміється теоретиками права як технологічна схема правової регуляції, володіючи знанням про яку, юристом усвідомлюються всі ланки, які пройде процес впровадження норми права в регульовані суспільні відносини, які перепони можуть 3'явитися на цьому шляху, а отже, здатний запропонувати

(C) Mitrofanov I., 2019

ORCID iD: https://orcid.org/0000-0002-1967-1985

k_kpd@dduvs.in.ua 
науково обгрунтований алгоритм підвищення дієвості правничого регулювання за рахунок зміцнення його основних ланок.

Самостійно норми права $є$ соціальними моделями та принципами навіть у частині конструювання тих або інших юридичних механізмів. Дослідження цих положень свідчить про потребу в перегляді змістовного навантаження досліджуваного явища. Механізм кримінальноправового регулювання має сприйматися як технологічна схема, що повинна використовуватися під час законотворчої діяльності.

Ключові слова: норми кримінального права, кримінально-правові відносини, механізм кримінально-правового регулювання, законотворення, юридичні факти, взаємні права та обов'язки, суб'єкти кримінально-правових відносин.

Problem statement. Today, hundreds of dissertations are proposed in Ukraine, which propose certain changes to the law, laws are passed, which have already been amended to the legislation of Ukraine on criminal liability (hereinafter - LUCL), for example, Laws No. 39XX of 10.09.2019, №. 101-XX of 18.09.2019, № 140-XX of 02.10.2019, № 263-XX of 31.10 .2019 , № 284-XX of 12.11.2019, to check the effectiveness of which only the mechanisms of criminal law and criminal law are possible implementation. The "stillbirth" norms are not capable of "running" these mechanisms, and even, "running" them, they will not fulfill the tasks of the Criminal Code (hereinafter referred to as the Criminal Code) of Ukraine, as defined by Article 1 of the Criminal Code of Ukraine. Therefore, the review of the new rules can only be a certain mechanism that, with all other legal instruments, will evaluate the effectiveness of a rule of criminal law.

The main purpose of criminal law, like any other branch of domestic law, is the specific (detailed) regulation of the most important social relations, with the purpose of which uses a whole range of various legal regulation. In its coordinated system-forming interaction on the achievement of the fixed in Art. 1 of the Criminal Code of the objectives of the objectives they form a single, well-coordinated mechanism. This mechanism is called "legal regulation mechanism" by theorists of law, and for criminal law we use the formulation - the mechanism of criminal legal regulation.

Analysis of publications that started solving this problem. Few criminal law theorists have dared to address the problems of this mechanism. And this is not surprising, since it shows all the phenomena of criminal law in dynamics, in their real functioning. At the same time, the following Ukrainian scientists studied the specific issues of mechanisms of criminal influence and criminal law regulation: Yu.V. Baulin, P.S. Berzin, M.I. Melnyk, V.O. Navrotsky, O.V. Naden, M.I. Panov, Ye.L Streltsov, D.S. Shapchenko, P.V. Khryapinsky and others. Foreign scientists-criminologists did not stay away from these problems: E.B. Blagov, V.K. Duyunov, V.P. Konyakhin, M.M. Kropachev, N.O. Lopashenko, G.O. Petrova, V.S. Prokhorov and others. However, the problems of the mechanism of criminal law regulation have not been finally resolved, since the role that is given to it to check the validity of the rule of criminal law in the author's understanding is still unknown $[1 ; 2 ; 3]$.

The article's objective. In view of the above, the purpose of the scientific publication is to model the concept of the mechanism of criminal law regulation, to whom the norm of criminal law is recognized not only as a basic element, but a construction that contains almost all the tools for the functioning of such mechanism for the purposes of the Criminal Code of Ukraine, and the value of the mechanism under consideration is also revealed.

Basic content. The mechanism of criminal law regulation can be defined as a system of various in nature and purpose of criminal legal means, which allow to fulfill the task of ensuring the protection of the most important values and prevention of criminal offense (a formal feature). Exploring the different viewpoints of scientists made it possible to conclude that scientists are consistently developing a mechanistic approach to the law as a whole and criminal law in particular. This is explained by the fact that the state implements the regulation of social relations, which are the subject of criminal law, by means of the rules of law, which are developed, fixed and applied. At the same time, the locomotive of criminal law regulation is the system of norms of criminal law, or more precisely, the system of norms of the Criminal Code of Ukraine. According to a mechanistic approach to criminal law regulation, the Criminal Code of Ukraine should be implemented in the real behavior of subjects through criminal relations, on the basis of which the latter arise and their dynamics (change, termination, termination, etc.). Without the relevant rules of the Criminal Code of Ukraine, these legal relationships can not exist. Criminal law regulation is a consequence of criminal law, a mechanism of systematic legal ordering of social relations $[4$, p. 117-118]. 
In addition to the rules of criminal law, the mechanism of criminal-legal regulation includes: legal facts or factual composition with such a decisive fact; criminal law relations (the requirements of criminal law are detailed for the respective subjects); an act of individual legal regulation (sentence, decision); system of means of criminal influence. The effectiveness of the mechanism of criminal law regulation depends directly on how well defined the tasks of regulation are and how optimally the means are chosen to fulfill them.

Analysis of different approaches to understanding the rules of law, as well as the features of the rules of criminal law [5, p. 89-106] allowed us to define the rule of criminal law as a mandatory rule for the non-commission of a criminal misdemeanor recorded by LUCL, and institutionally combined with it a command enforced by the enforcement potential of criminal remedies. It is fundamental, however, that the development and enforcement of criminal law rules that punish a criminal offense, and their subsequent application, is given some specificity, because such rules generally seem to be outside the rules of both criminal and criminal law. Other areas of law that provide for the legal protection of regulated public relations. Norms of criminal law are usually formulated as lists of definitions of socially dangerous acts that are transformed into LUCL in the duty of their non-compliance, and sanctions corresponding to the nature and degree of public danger of those actions. Therefore, the LUCL article does not fully describe the prohibited behavior (its features are not disclosed).

Criminal law norms give rise to relevant legal relations, the legal specificity of which is that: 1) their participants are only legal entities (persons with legal personality). As regards preventive criminal-law relations, they have as a subject of criminal law all citizens, including lawabiding citizens; 2) arise in the presence of the relevant rules of criminal law; 3) characterized by a connection of subjects in the form of correspondent subjective rights and legal obligations; 4) arise solely on the basis of a legal fact (actual composition). In view of this, O.S. Ioffe and M.D. Sharhorodsky notes that legal relations arise not simply from legal facts, but from changes specified in the law, which must "undergo" actual relations as a result of their occurrence $[6, \mathrm{p}$. 181]. As for the activity regulated by the procedural criminal law of Ukraine, it should be borne in mind that the legal fact of the emergence of procedural criminal-legal relations is not a legal or even objective circumstance, but signs of an objective, legally significant (relevant for the court) the circumstances that led to the model of restorative criminal-law relations; 5) are established, guaranteed and protected by the government [7, p. 271-272].

If we know what constitutes a mechanism for criminal law regulation, a fair question arises as to what we should do with this knowledge and what its practical content is. Each of the structural parts we study is an independent legal category that is fundamental and has been studied in legal science for a long time and sufficiently deep. In criminal law textbooks there are no chapters on the mechanism of criminal law regulation at all. So what is his knowledge for? What is the idea of the mechanism of criminal law regulation. What is the purpose of combining these legal phenomena into a single mechanism of criminal legal regulation?

In our opinion, to know how criminal law works ("works"). The knowledge that we have thus obtained, summarized and presented as the only mechanism is necessary for proper law-making. In order for a legal fact to be the basis for the emergence of criminal law relations, it must meet all the requirements of legislative technology. Yes, if the legislator tries to enforce the legal protection of amber and to counteract it with criminal means as an encroachment on social relations that provide environmental protection, rational use of its resources and environmental safety as a special environmental condition that meets the criteria set in the legislation, , the limits and standards that determine its purity, resource-intensiveness (environmental), environmental sustainability, species diversity, ability to satisfy people's interests, he/she must design his composition as a criminal offense against the environment.

For example, on September 2, the Head of State instructed the Verkhovna Rada to approve the Amber Extraction Bill by 01.12.2019. 09/04/2019 V.O. Zelensky submitted to the Parliament of Ukraine as an urgent bill "On Amendments to the Criminal Code of Ukraine on Criminal Responsibility for Illegal Extraction of Amber or Move It Across the Customs Border of Ukraine". The said bill proposes Part 1 of Art. 201 of the Criminal Code of Ukraine (hereinafter referred to as the Criminal Code), after the words "cultural values", supplement with the word "amber", para. 1 h. 2 tbsp. 240 shall be supplemented with the words "except in cases provided for in other articles of the Criminal Code of Ukraine" and also supplemented by the Criminal Code of Ukraine with Article 2401 "Illegal extraction of amber". At the same time, this criminal offense is proposed as a criminal offense against the environment with its location in the Criminal Code of Ukraine after Art. 240 "Violation of the rules of protection or use of subsoil". 
Part 1 of Art. 2401 of the Criminal Code of Ukraine proposes to punish the illegal extraction of amber in the form of a fine from seven hundred to three thousand non-taxable minimum citizens' incomes (hereinafter - NTMCI) or restriction of liberty for a term of one to three years, or imprisonment for the same term. Part 2 of Art. 2401 of the Criminal Code of Ukraine - for the sale, purchase, storage, transfer, transfer, transportation, processing of illegally harvested amber in the form of a fine from three thousand to ten thousand NTMCI or restriction of freedom for a term of three to six years, or imprisonment for the same term. Part 3 of Art. 2401 of the Criminal Code of Ukraine - for the actions envisaged by h. 1 or 2 of this Article, committed by prior agreement of a group of persons either repeatedly or in considerable amounts, as well as the actions provided for in part one of this Article, committed in the territories or objects of the nature reserve fund, in the form of imprisonment for a term four to seven years.

In the proposed embodiment, the criminal offense under Art. 2401 of the Criminal Code of Ukraine, under no circumstances can be attributed to criminal offenses against the environment. This is explained by the fact that when attributing certain actions to criminal offenses against the environment, it is necessary to focus on their environmental friendliness. The sign of environmental friendliness by which the legislator refers socially dangerous acts to criminal offenses against the environment, as relatively independent in the system of the Special part of the Criminal Code, is related to the social and natural justification of the direct interaction of society and man with the environment, the level of prospects of scientific technologies, diversity of anthropogenic impact on the environment. Distinctive features of criminal offenses against the environment are: development of components of environment and natural resources as a basis for a certain type of activity; focus on the use of environmental objects that is directly prohibited by the CC; contact socially condemned impact on environmental objects that alters its natural (normal) state or individual indicators of its objects; violation of the right to an environmentally safe environment, which holds a special place in the system of constitutional rights and freedoms of individuals, because it covers the whole set of ecological constitutional rights of man and acts as a guarantee of the right to life and the right to health care.

In other words, formulating a criminal offense against the environment requires that it encroach on the generic object of these criminal offenses. The focus of action on this object is reflected in the formulation of the relevant consequences - creating a danger to life, health or environment, or causing appropriate harm to life, human health or the environment $[8-11 ; 12$, p. 208-211]. Therefore, the draft Article 2401 of the Criminal Code of Ukraine on the illegal extraction of amber is superfluous given the existence in the criminal law of Article 240, part 1 of which punishes for violation of the established rules for the protection of subsoil, if it created a danger to life, human health or the environment, in the form of a fine of three hundred to six hundred NTMCI, or restraint of liberty for a term up to two years, or imprisonment for the same term. The wording of parts 2 and 3 (except for the use of the phrase in part 3 of Article 2401 of the Criminal Code of Ukraine "actions envisaged by part one of this Article committed in the territories or objects of the nature reserve fund"), in my opinion, indicates the illegality of the turnover illegally harvested amber. Considering that the President of Ukraine proposes to legalize the production of amber, the violation of the established order of circulation of illegally harvested amber will constitute a criminal offense in the sphere of economic activity, the object of which is the protected state system in the public relations, which are protected by the state in the economic sphere. a society oriented towards the perspective of the market economy of Ukraine [13, p. 154-157].

Due to the fact that Article 240 is sufficient for counteracting the illegal amber production in the Criminal Code of Ukraine. to place under Art. 213 of the Criminal Code of Ukraine "Violation of the procedure for scrap metal operations". At the same time, when formulating a criminal offense, it is enough to point out the implementation of the relevant actions by entities that do not have the appropriate licenses for the right to engage in appropriate activities with Amber. Provide for mandatory licensing of amber-related activities, including mining, amber, in business law.

In addition, one of the main foundations of any branch of law, the more criminal, is the principle of legality. According to Part 2 of Art. 3 of the Criminal Code of Ukraine "The laws of Ukraine on criminal liability (hereinafter referred to as" LUCL"), adopted after the entry into force of the Criminal Code of Ukraine, are included in it after their entry into force, that is, not any, but the LUCL. Today, I state the "secrecy" of changes to the Criminal Code of Ukraine. Thus, the Law of Ukraine "On Special Procedure for Removal of the President of 
Ukraine from office (impeachment)" of September 10, 2019 № 39-IX para. 1 h. 2 tbsp. 351 of the Criminal Code of Ukraine, as amended, the Law of Ukraine "On Amendments to Certain Legislative Acts of Ukraine on Ensuring the Effectiveness of the Institutional Mechanism for Prevention of Corruption" of October 2, 2019 No. 140-IX, amended the note to Art. 45 of the Criminal Code of Ukraine.

The Bill "On Prevention and Counteraction to Legalization (Laundering) of Proceeds of Crime, Financing Terrorism and Financing the Proliferation of Weapons of Mass Destruction", submitted by the Cabinet of Ministers of Ukraine and adopted by the Verkhovna Rada of Ukraine in its first reading on 1 November 2019 Part 2 of Art. 962, pp. 3, 5, n. 2 notes Art. 963, Part 2 and 3 Art. 964, para. 4 and 5 h. 2 tbsp. 967, Part 1 Art. 969, para. 2 h. 1, para. 2 h. 2 tbsp. 2051, Art. 209, Art. 2091, Part 1, Art. 2585, Art. 306 of the Criminal Code of Ukraine, as well as to supplement the Criminal Code of Ukraine with Articles 2586 "Passing the Terrorism Training" and 2587 "Departure from Ukraine and Entry into Ukraine for Terrorist Purpose".

Thus, Part 1 of Art. 2586 it is proposed to impose a penalty for the training of terrorism, that is, to obtain instructions from a person, including the acquisition of knowledge or practical skills, from another person concerning the manufacture or use of explosives, firearms or other weapons or harmful or dangerous substances, or other specific methods or techniques for for the purpose of organizing, preparing or committing the criminal offenses provided for in Articles 258 to 2585,2587 of the Criminal Code of Ukraine, in the form of imprisonment for a term of three to eight years from confiscation this property or without it.

The amending of the Criminal Code of Ukraine with new components of terrorist offenses looks a bit strange, since the arsenal of existing criminal-law standards of the Special Part is enough today to counter terrorism. This raises some questions about understanding the content of existing criminal law standards aimed at counteracting this. Thus, Article 2584 of the Criminal Code of Ukraine establishes punishment for recruiting, arming and training a person for the purpose of committing a terrorist act, as well as using a person for this purpose in the form of imprisonment for a term of three to eight years with or without property confiscation.

The listed forms of the said offense (2584 of the Criminal Code of Ukraine) are recognized at the present stage by fairly widespread forms of criminal unlawful behavior. In this case, arms are recognized as supplies to persons involved in terrorist activities of all kinds of weapons, explosives and explosive devices, training is the passage of military and sabotage training required to commit criminal offenses of a terrorist nature, requiring special skills. weapons, the manufacture or use of explosives, harmful or dangerous substances, tactical methods of warfare in various conditions, including battle in settlements, etc.). At the same time, such actions are part of the objective side of the criminal offenses envisaged by Art. 2583 and 260 of the Criminal Code of Ukraine. In addition, the actions that make up the objective side of the criminal offense set out in Art. 2581 of the Criminal Code of Ukraine "Involvement in the Commitment of a Terrorist Act" and the use of a person for the purpose of committing a terrorist act (Article 2584 of the Criminal Code of Ukraine), which consists in the direct use of such person in the commission of a terrorist act.

In this case, there is a certain competition of the already existing criminal law norms (Article 2583, Article 260, Article 2581 of the Criminal Code and Article 2584 of the Criminal Code of Ukraine) on some features of the objective side, as phenomena of negative and undesirable caused by subjective factors (defects in lawmaking techniques, regulatory redundancy, the emergence of new concepts without regard to their mandatory systematic statement, lack of a clearly motivated criminal policy, the concept of construction LUCL. And the legislator also tries to introduce the rules separately get up the penalties for training terrorism (Article 2586 of the Criminal Code of Ukraine) and departure from Ukraine and entry into Ukraine for terrorist purposes (Article 2587 of the Criminal Code of Ukraine). or other actions. Finally, this approach may cause lawmakers errors in enforcement activity during the qualification assessment of certain acts.

Conclusions. The mechanism of legal regulation has recently been understood by law theorists as a technological scheme of legal regulation, with the knowledge of which the lawyer is aware of all the links that will pass the process of implementing the rule of law in regulated social relations, which obstacles may meet along the way, and therefore able to offer a scientific proposal. an algorithm for increasing the effectiveness of legal regulation by strengthening its core links. Without exaggeration, it can be said that, after the law is drafted and passed, a highly effective mechanism for implementing its rules can be refined, but ignoring a sufficiently rigid relationship between the legal structure and the model of the criminal law norm is a 
factor, at least, one of the factors of the low-quality level of legislative acts. The rules of law themselves are social models and principles, even in the construction of certain legal mechanisms. The study of these provisions indicates the need to review the substantive load of the phenomenon under study. The mechanism of criminal law regulation should be perceived as a technological scheme, which should be used in lawmaking activities. Scientists have a mechanism of criminal law regulation should act as a guideline for testing their legislative proposals and checking proposals to change the sanctions of certain criminal legal norms of the Special part of the Criminal Code of Ukraine.

\section{References}

1. Митрофанов I. I. Поняття кримінально-правових норм та їх види в механізмі реалізації кримінальної відповідальності. Європейські перспективи. 2016. № 1. С. 65-72.

2. Митрофанов I. І. Кримінально-правова норма та пов'язані з нею веління. Публічне право. 2016. №1 (21). С. 172-179.

3. Митрофанов I. I. Кримінально-правовий норматив і норма кримінального права. Вісник Південного регіонального иентру Національної академії правових наук Украӥни. 2017. № 12. С. 70-78.

4. Митрофанов I. I. Механізм кримінально-правового регулювання: монографія. Кременчук: Видавець ПП Щербатих О. В., 2019. 480 с.

5. Митрофанов И. И. Механизм реализации уголовной ответственности : монография. Кременчуг : Изд. ЧП Щербатых А. В., 2011. 616 с.

6. Иоффе О. С., Шаргородский М. Д. Вопросы теории права. М. : Госюриздат, 1961. 381 с.

7. Фаткулин Ф. Н. Проблемы теории государства и права: учеб. пособие. Казань : Изд-во КЮИ МВД России, 2002. 351 с.

8. Митрофанов I. І. Злочини проти довкілля: навч. посібник. Кременчук : Вид. ПП Щербатих О.В., 2009. 100 с.

9. Митрофанов I. I. Кримінально-правове забезпечення охорони довкілля: монографія. Кременчук : Видавець «ПП Щербатих О. В.», 2010. 272 с.

10. Митрофанов I. І., Притула А. М. Злочини проти довкілля: навч. посібник. Суми : Видво «Університетська книга», 2010. 205 с.

11. Митрофанов I. І., Локтіонова В. В. Довкілля під охороною закону про кримінальну відповідальність: монографія. Кременчук : Видавець «ПП Щербатих О. В.», 2011. 420 с.

12. Митрофанов І. І., Білоус Ю. І. Шкода навколишньому природному середовищу як ознака злочинів проти довкілля. Актуальні проблеми кримінального права, процесу та криміналістики: матер. II Міжнар. наук.-практ. конф. (м. Одеса, 8 жовтня 2010 р.). Одеса : ПП «Фенікс», 2010. С. 208-211.

13. Митрофанов I. I. Загальна характеристика та види злочинів у сфері господарської діяльності. Вісник Кременчуцького державного політехнічного університету. 2009. № 4. С. 154-157.

Received to editorial office 10.12.2019

1. Mitrofanov, I. I. (2016) Ponyattya kryminal'no-pravovykh norm ta yikh vydy v mekhanizmi realizatsiyi kryminal'noyi vidpovidal'nosti [The concept of criminal legal rules and their types in the mechanism of implementation of criminal liability]. Yevropeys'ki perspektyvy. № 1. S. 65-72.

2. Mitrofanov, I. I. (2016) Kryminal'no-pravova norma ta pov"yazani z neyu velinnya [Criminal legal rule and related orders]. Publichne pravo. №1 (21). S. 172-179.

3. Mitrofanov, I. I. (2017) Kryminal'no-pravovyy normatyv i norma kryminal'noho prava [Criminal legal rule and rule of criminal law]. Visnyk Pivdennoho rehional'noho tsentru Natsional'noyi akademiyi pravovykh nauk Ukrayiny. № 12. S. 70-78.

4. Mitrofanov, I. I. (2019) Mekhanizm kryminal'no-pravovoho rehulyuvannya [The mechanism of criminal legal regulation] : monohrafiya. Kremenchuk: Vydavets' PP Shcherbatykh O. V.,. $480 \mathrm{~s}$.

5. Mitrofanov, I. I. (2011) Mekhanizm realizatsii ugolovnoy otvetstvennosti [The mechanism of implementation of criminal liability]: monografiya. Kremenchug : Izd. ChP Shcherbatykh A. V., 616 s.

6. Yoffe, O. S., Sharhorodskiy, M. D. (1961) Voprosy teorii prava [Issues of the theory of law]. M. : Gosyurizdat, $381 \mathrm{c}$.

7. Fatkulin, F. N. (2002) Problemy teorii gosudarstva i prava [Problems of the theory of state and law]: ucheb. posobiye. Kazan' : Izd-vo KYuI MVD Rossii, 351 s.

8. Mitrofanov, I. I. (2009) Zlochyny proty dovkillya [Environmental crimes]: navch. posibnyk. Kremenchuk : Vyd. PP Shcherbatykh O.V., $100 \mathrm{~s}$.

9. Mitrofanov, I. I.(2010) Kryminal'no-pravove zabezpechennya okhorony dovkillya [Criminal legal support of environmental protection]: monohrafiya. Kremenchuk : Vydavets' «PP Shcherbatykh O. V.», $272 \mathrm{~s}$.

10. Mitrofanov, I. I., Prytula, A. M. (2010) Zlochyny proty dovkillya [Environmental crimes]: navch. posibnyk. Sumy : Vyd-vo «Universytet $\cdot \mathrm{s}^{\prime} \mathrm{ka}$ knyha», $205 \mathrm{~s}$.

11. Mitrofanov, I. I., Loktionova, V. V. (2011) Dovkillya pid okhoronoyu zakonu pro kryminal'nu vidpovidal'nist' [The environment under the protection of the law on criminal liability]: monohrafiya. Kremenchuk : Vydavets' «PP Shcherbatykh O. V.», 420 s.

12. Mitrofanov, I. I., Bilous, Yu. I. (2010) Shkoda navkolyshn'omu pryrodnomu seredovyshchu yak oznaka zlochyniv proty dovkillya [Harm to the environment as a sign of crimes against the environ- 
ment]. Aktual'ni problemy kryminal'noho prava, protsesu ta kryminalistyky: mater. II Mizhnar. nauk.prakt. konf. (m. Odesa, 8 zhovtnya 2010 r.). Odesa : PP «Feniks», S. 208-211.

13. Mitrofanov, I. I. (2009) Zahal'na kharakterystyka ta vydy zlochyniv u sferi hospodars'koyi diyal'nosti [General characteristics and types of crimes in the field of economic activity]. Visnyk Kremenchuts'koho derzhavnoho politekhnichnoho universytetu. № 4. S. 154-157.

\section{Summary}

There is the analysis of the mechanism of criminal legal regulation from the point of view of its structure. The key categories of this mechanism have been considered - the rules of criminal law and criminal law relations.

The importance of the mechanism of criminal law regulation for law-making is shown through concrete examples of legislative novelties.

Keywords: criminal law norms, criminal law relations, mechanism of criminal law regulation, lawmaking, legal facts, mutual rights and obligations, subjects of criminal legal relations.

UDC 343.232

DOI 10.31733/2078-3566-2019-5-183-189

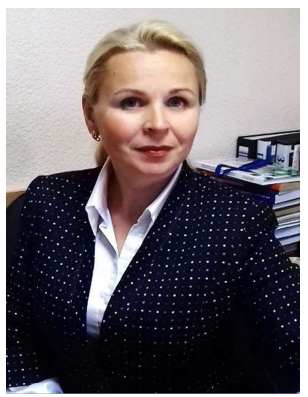

Hanna FEDOTOVA ${ }^{\circledR}$

Dr of Law, Sr Research Fellow (State Research Institute of the Ministry of Internal Affairs of Ukraine)

\section{CRIMINAL AND LEGAL ESSENCE OF THE «CRIMINAL OFFENSE» CATEGORY}

Ганна Федотова. КРИМІНАЛЬНО-ПРАВОВА СУТНІСТЬ КАТЕГОРІї «КРИМІНАЛЬНИЙ ПРОСТУПОК». 3 метою визначення кримінально-правової сутності категорії кримінальний проступок проаналізовано дефініцію «кримінальне правопорушення» як родового (дочірнього) поняття та охарактеризовано видові (похідні) поняття «злочин» та «кримінальний проступок». Розкрито усвідомлення сутності явища «кримінальний проступок» в кримінальноправовій науці за результати якої доведено притаманність злочинної природи кримінальному проступку.

Зазначено, що, незважаючи на те, що вчені-правознавці достатньо давно вивчають проблеми кримінальних проступків, в усвідомленні сутності цього явища в кримінально-правовій науці та практиці бракує одностайності.

На підставі аналізу думок науковців зроблено висновок, що термін «проступок» здебільшого використовується як тотожне при визначенні правопорушення, без якогось змістового розмежування. Таке ототожнення, на нашу думку, некоректне, оскільки правопорушення $є$ більш загальним поняттям та за чинним законодавством охоплює всі види проступків і злочини.

Наголошено на притаманності кримінальному проступку злочинної природи, підтвердженням чого є прийняття 22 листопада 2018 року Верховною Радою України Закону України «Про внесення змін до деяких законодавчих актів України щодо спрощення досудового розслідування окремих категорій кримінальних правопорушень» (№7279-д). Після набуття ним чинності 1 вересня 2020 р. буде введено в дію положення щодо урегулювання питання кримінальних проступків, наділяючи вказану категорію статусом одного 3 видів кримінального правопорушення, за яке передбачено кримінальну відповідальність, використовуючи при цьому виокремлюючи критерії - ступінь суспільної небезпеки, вид і міру покарання. Відповідно до положень Закону «кримінальним проступком» $є$ передбачене Кримінальним кодексом діяння (дія чи бездіяльність), за вчинення якого передбачене основне покарання у виді штрафу в розмірі не більше трьох тисяч неоподатковуваних мінімумів доходів громадян або інше покарання, не пов'язане $з$ позбавленням волі.

Ключові слова: кримінальне правопорушення, злочин, кримінальний проступок, кримінальне прочесуальне законодавство, кримінальне законодавство.

Problem statement. With the adoption of the Criminal Procedure Code of Ukraine in 2012 (hereinafter referred to as the CPC), in addition to the «crime», the only criminal, socially dangerous and harmful act for which criminal liability may occur, such concept as «criminal

(C) Fedotova H., 2019

ORCID iD: https://orcid.org/0000-0002-7798-3143

dndi@mvs.gov.ua 